\title{
Allergic diseases of the skin and drug allergies - 2022. Consensus statement on management of urticaria in India
}

\author{
Kiran Godse
}

From 2nd WAO International Scientific Conference (WISC 2012)

Hyderabad, India. 6-9 December 2012

\section{Background}

Urticaria, a heterogeneous group of diseases, often cannot be recognized by its morphology. Due to non-specific and non-affordable diagnosis, management of urticaria, especially chronic urticaria, is very challenging. This guideline includes definition, causes, classification and management of urticaria. Urticaria has a profound impact on the quality of life and causes immense distress to patients, necessitating effective treatment. One approach to manage urticaria is identification and elimination of the underlying cause(s) and/or eliciting trigger (s), while the second one is treatment aimed at providing symptomatic relief. This guideline recommends use of second-generation non-sedating $\mathrm{H} 1$ antihistamines as the first-line treatment. The dose can be increased up to four times to meet the expected results. In case patients still do not respond, appropriate treatment options can be selected depending on the cost.

First-generation antihistamines can interfere with rapid eye movement (REM) sleep and impact on learning and performance. New GA $^{2}$ LEN/EDF/EAACI/WAO guidelines do not recommend the use of these sedating antihistamines for the routine management of $\mathrm{CU}$ as the firstline agents. Second-generation antihistamines should be considered as the first-line symptomatic treatment for urticaria because of their good safety and tolerability pro-

w5

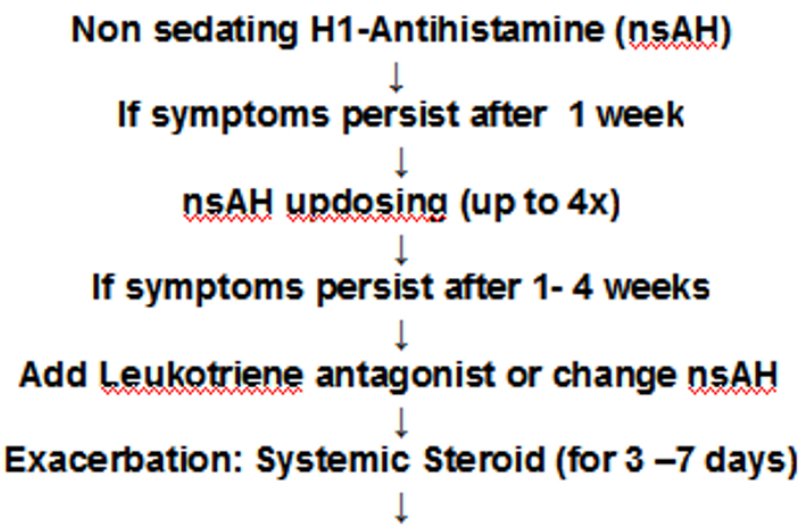

Add Ciclosporin A, Methotrexate, H2-antihistamine, Dapsone, Omalizumab.Autoserum therapy

Figure 1 Results Diagram.

Dermatology, DR.D.Y.Patil Medical College and Hospital, India

(c) 2013 Godse; licensee BioMed Central Ltd. This is an Open Access article distributed under the terms of the Creative Commons Attribution License (http://creativecommons.org/licenses/by/2.0), which permits unrestricted use, distribution, and reproduction in any medium, provided the original work is properly cited. 
file.Second-generation antihistamines in higher doses have been shown to be effective in control of chronic spontaneous urticaria. This has been verified in studies using even up to fourfold higher than recommended doses of desloratadine, fexofenadine, levocetirizineand rupatadine.

\section{Methods}

Approach to chronic spontaneous urticaria.

\section{Results}

See Results Diagram in Figure 1.

\section{Conclusions}

Four-fold updosing of antihistamines is recommended in urticaria management by Indian consensus statement.

Published: 23 April 2013

doi:10.1186/1939-4551-6-S1-P109

Cite this article as: Godse: Allergic diseases of the skin and drug

allergies - 2022. Consensus statement on management of urticaria in

India. World Allergy Organization Journal 2013 6(Suppl 1):P109.

Submit your next manuscript to BioMed Central and take full advantage of:

- Convenient online submission

- Thorough peer review

- No space constraints or color figure charges

- Immediate publication on acceptance

- Inclusion in PubMed, CAS, Scopus and Google Scholar

- Research which is freely available for redistribution

Submit your manuscript at www.biomedcentral.com/submit 